\title{
Remote sensing and sig contribution for the identification of the fracturation influence on the drainage network architecture in the High Ziz River basin, Central High Atlas, Morocco
}

\author{
Khadija Diani $^{1 \star}$, Ilias Kacimi ${ }^{1}$, Hicham ElBelrhiti ${ }^{2}$, Mahmoud Zemzami ${ }^{3}$, Hassan Tabyaoui ${ }^{4}$, \\ Lhoussaine Masmoudi ${ }^{5}$
}

${ }^{1}$ LGEE Laboratory, Department of Earth Sciences, Faculty of Sciences, Mohammed V-Agdal University, Rabat, Morocco, e-mail: diani.khadija@gmail.com $\left({ }^{*}\right.$ corresponding author)

${ }^{2}$ Département des Sciences Fondamentales et Appliquées (DSFA), Institut Agronomique et Vétérinaire Hassan II. BP N 6202

Madinat Alirfan, Rabat, Morocco

${ }^{3}$ Ministry Delegate to the Minister of Energy, Mines, Water and Environment, in charge of water, Rabat, Morocco

${ }^{4}$ Natural Resources and Environment Laboratory, Polydisciplinary Faculty of Taza, Sidi Mohamed Ben Abdullah University, Fez, Morocco

${ }^{5}$ LCS Laboratory, Physics Department, Faculty of Sciences, Mohammed V-Agdal University, Rabat, Morocco

\begin{abstract}
This study aims to contribute to a better estimation of the density of fractures likely to favour the drainage of surface water in the High Ziz River (HZR) basin. The method adopted consists of the use of different airborne image processing techniques (filtering, enhancement and slope analysis) which allow a good discrimination of image discontinuities (lineaments) that can then be used for producing lineament maps. The influence of these lineaments on the underground flow is then studied. Indeed, it was possible to extract the lineament network, following the exploitation of remote sensing and an objectively completed analog analysis using the PCI Geomatica LINE module and its directional filters (Sobel directional filters by the ACP method), and to extract the hydrographic network of the HZR basin, using the ArcHydro tool. After superimposing these data, their thematic maps (of the lineament and hydrographic network) were developed. In addition, this comparison of the two hydrographic networks and lineament maps showed us very varied flow directions influenced by geological structures, particularly fracturing. The topography of the region also has a secondary impact on flows through the presence of slopes generally oriented towards the SE of the basin. The correlation of the results with the different directions of the orders of the hydrographic network allowed us to identify the potential effects of lineaments on the orientations of surface water circulation. In addition to these results, the realization of the Rose diagram indicated that the dominant trend in lineaments is N90-45N ${ }^{\circ}$ (NE-SW).
\end{abstract}

Key words: lineaments, drainage network, High Ziz River, automatic extraction and remote sensing

\section{Introduction}

In hydrology and hydrogeology, the mapping of fractures and fissures (faults and geological contacts) has a very important role. Indeed, they favour the circulation of water, and they contribute to storing or facilitating the flow of water to the outlet. The work of Saley (2003), Jourda (2005) and Youan (2008) has shown that these fractures are responsible for the accumulation of groundwater in fissured basement environments and constitute the areas by excellence of water flow. This leads to the topographic depressions, hydrographic network and vegetation anomalies (Yatabe et al. 1984; Soesilo and Hoppin 1986; Oubbih et al. 2015).
Lineament maps, often presented in geological maps, are tools of major economic interest. Their importance is primarily in the choice of potential sites to shelter engineering structures (dams, bridges, highways etc.), surface and groundwater management, understanding and management of natural and environmental disasters such as landslides, earthquakes, pollution and floods (Marghany 2010).

The mapping of lineaments and fractures is particularly important in the field of hydrology, especially for the management of groundwater and surface water and the orientation of their circulation. The advent of observation satellites has greatly facilitated mapping work, which now has a very global view of the earth's surface. 
The detection and extraction of lineaments by remote sensing and satellite images can be divided into three categories (Katsuaki 1995; Walsh and Clark 2000):

- enhancement of image quality and extraction of lineaments after characterization of the geological structure,

- geological mapping based on image classification and detection, using a spectral signature, of anomalies attributable to mineralization,

Using a geographic information system to superpose satellite images on geological, geophysical and geochemical databases.

Lineaments and fractures are among the key parameters that guide the flow of water by accelerating erosion and weathering. They are among the determining parameters that guide water circulation through accelerated erosion and weathering. Furthermore, the hydrographic network often uses areas of weakness in order to minimize the energy required for its flow (Deffontaines 1990; Oubbih et al. 2015).

The objective of our work is to map lineaments and fractures in the High Ziz River (HZR) basin (High Atlas, Morocco) using a Landast 8 OLI image, acquired on July 8,2018 , in the dry season without cloud cover. They can be considered among the determining parameters that guide water circulation through accelerated erosion and alteration. In addition, the hydrographic network often uses areas of weakness in order to minimize the energy required for its flow (Deffontaines 1990), which in turn facilitates the quantification of the directional influence of these lineaments on the flow of the hydrographic network, on the orientation of water surface circulation and on groundwater storage.

\section{Study area}

The current study focusses on the highest part of the HZR basin (Fig. 1). It expands from the eastern part of the Central High Atlas to the western part of the Eastern High Atlas. It is limited in the North by the Upper Moulouya (Eastern Meseta) and in the South by the Eastern part of the Anti-Atlas. Its ecosystems have experienced significant changes in recent years due to several factors, including anthropogenic factors and ecological constraints. According to what has already been mentioned, the study area extends from the far east of the Central High Atlas to the western part of the Eastern High Atlas.

The area of the basin is 4001.3 sq. $\mathrm{km}$. It is a mountainous area, with a wide range of variation in altitudes (from 3499 - in the Zaouiat Sidi Hamza to less than 1149 m a.s.l. in the Outlet of Foum Zaabel), complex topography and dominated by steep slopes. Relief and lithology shows that the High Ziz basin consists essen-

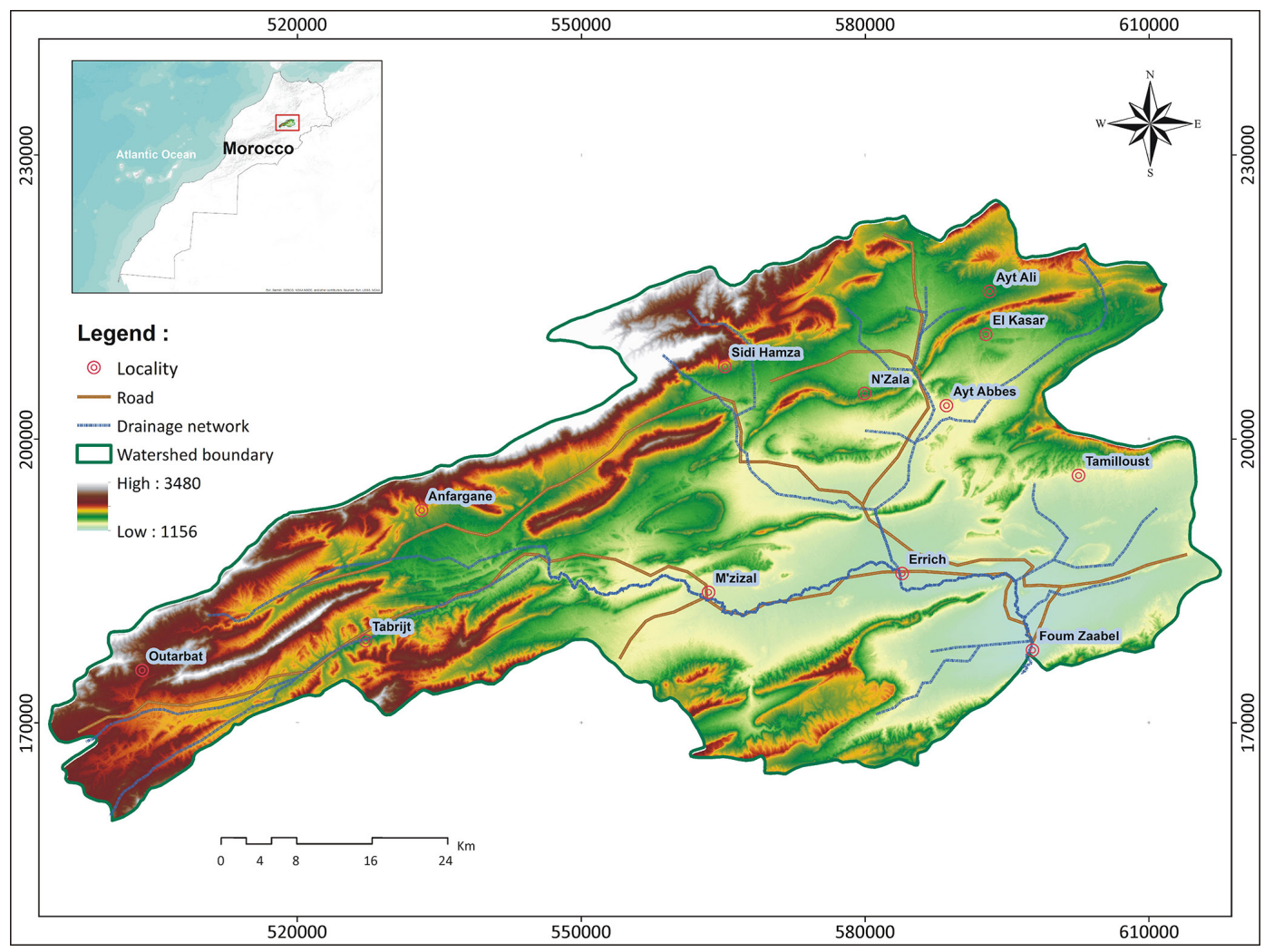

Fig. 1. Location of the High Ziz River basin, South-East of Morocco 
tially of dolomite, limestone, calcareous marl alternations, and silico-clastic detritus (Igmoullan 2001).

The Ziz River runs North-South across the Paleozoic area (limestone, shale and clays), the Inner Sierras (limestones and sandstones) and the Flysch Sector. It then arrives at the Inner Depression (marls), and runs northward until the Outlet of Foum Zaabel.

\section{Materials and methods}

The various pre-processing and treatments were carried out using ENVI 5.3 software, the PCI Geomatics software through its LINE module, which was used for the automatic extraction of lineaments. Finally, the ArcGIS software was used to extract the statistical parameters of the lineaments (number and length).To produce the directional rose diagram; we used RockWorks 2016 software.

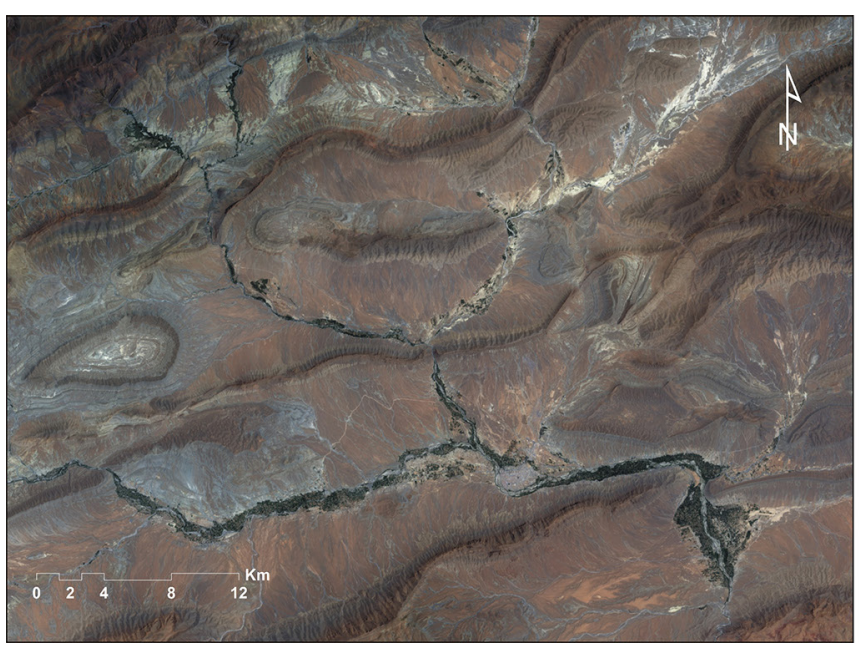

Fig. 2. Results after Radiometric correction and Atmospheric Reflectance of Landsat 8 OLI by ENVi 5.3

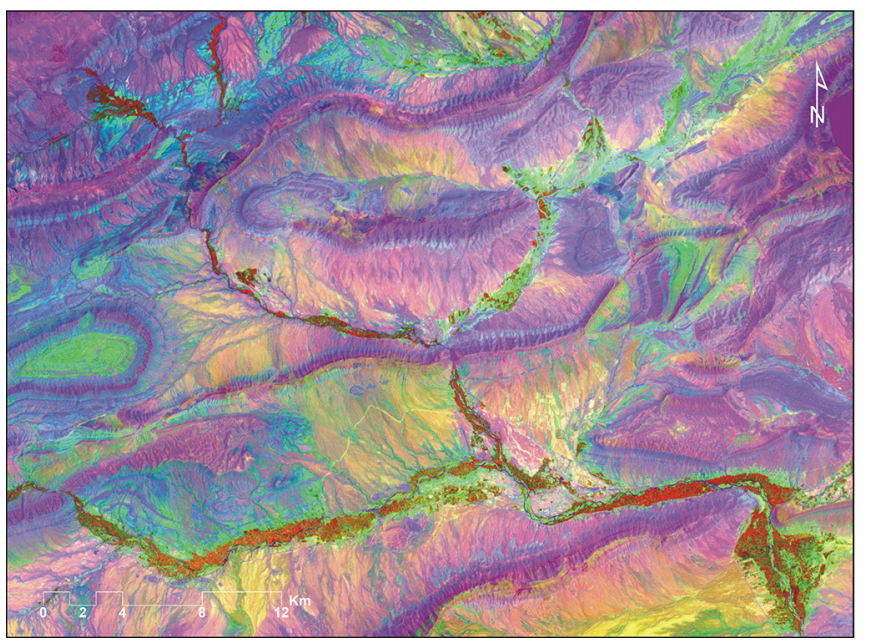

\section{Exploitation of remote sensing images Landsat-8 OLI processing}

Lineaments represent linear geological objects or alignments of geological objects close to each other, topographic discontinuities or geomorphological structures inherited from ancient topography.

The methodology of optical satellite image processing and lineament extraction is a synthesis of Kouamé et al. (1999), Gronayes (2003), Jourda (2005) and Youan (2008). The preliminary phase to processing Landsat 8 OLI images consisted of the creation of a mosaic of three previously corrected scenes (calibration points found on the OLI bands). This includes specific treatments (contrast enhancement, main Component Analysis) and combinations of directional bands and filters for lineament identification. After processing and corrections made on a single spectral band (B7), polylines and segments are generated (Radiance stacking) (Fig. 2 ). The method we have adopted to extract the linea-
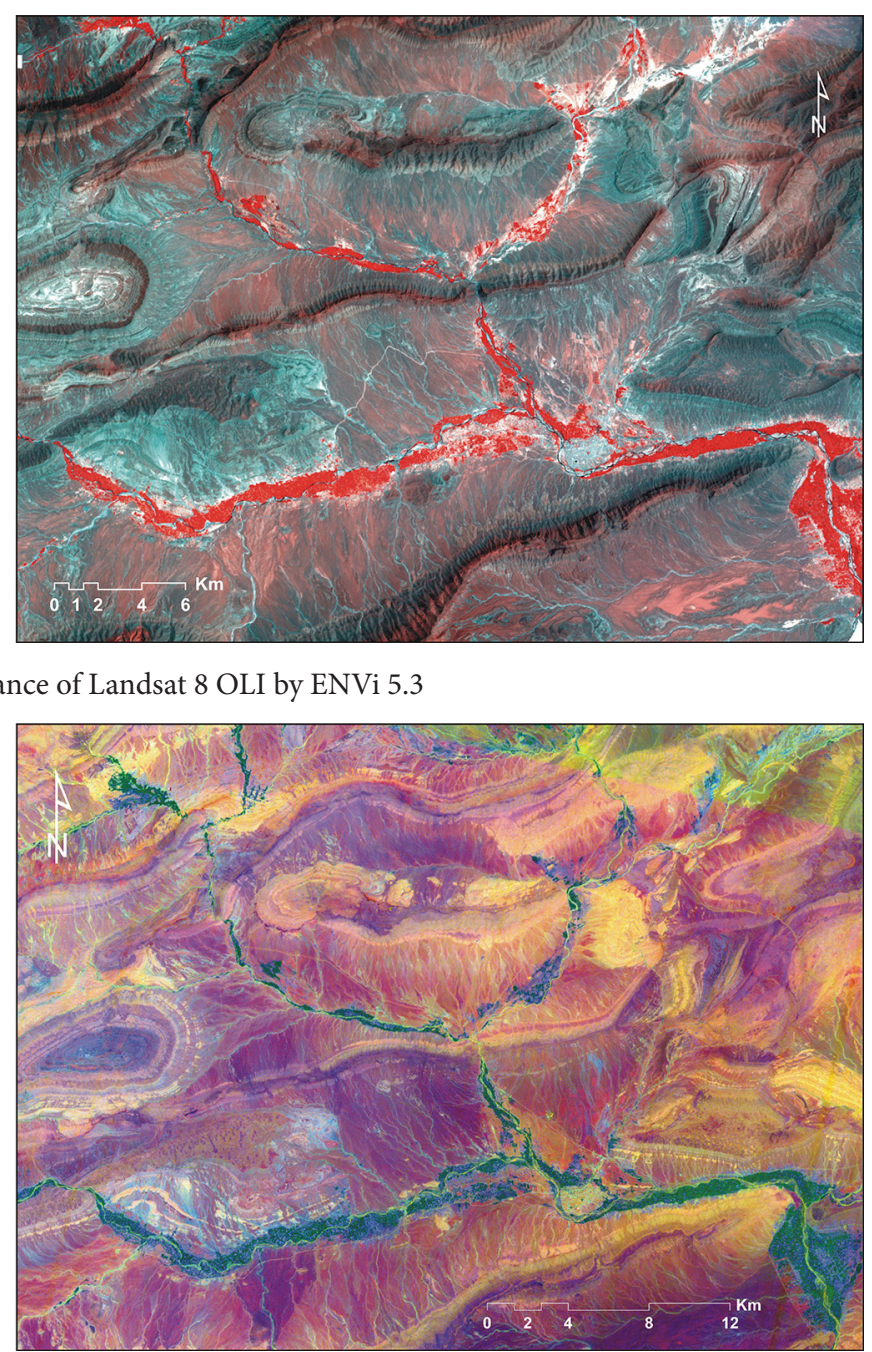

Fig. 3. Images obtained with the first three bands of the PCI: PC1, PC2, and PC3 
ments is initially based on improving image quality by applying Principal Component Analysis (PCA) (Fig. 3). We then applied Sobel's directional filters to the image processed by the PCA method.

PCA is an effective technique based on statistical analysis and repository change, which allows the accentuation of a multi-spectral image of fine interpretations (Biémi 1992). It reduces the information contained in several bands, sometimes highly correlated, into a smaller number of components. The treatments and filtering have the effect of accentuating and facilitating the detection of discontinuities in images, thus allowing them to be surveyed by simple visual observation. Only lineaments of structural origin are of interest in this study.

\section{Lineament extraction PCI LINE algorithm}

The extraction of lineaments using PCI's LINE algorithm is performed in a single spectral band and generates polylines and segments.

After extraction, it can be seen that the distinction between lineaments is easy (Fig. 4); there are representatives of the regional structure and those associated with the hydrographic network and roads, tracks, high voltage lines, forest boundary layers and cultivated areas, which were identified in all lineaments and eliminated.
Geological and structural lineaments identified during previous mapping works (Papon 1973; Rompel et al. 1998; Biémi 1992), which, although few in number and based on aerial photographs and field observations and therefore considered as proven, have been included in our lineament network. This effectiveness of the method, based on the interpretation of satellite images, in finding real fractures already known, and not only the largest, validates our extraction method. This validation then leads us by extrapolation to give a structural value to all our lineaments and to move from the use of the term lineament to that of the fracture.

\section{Linear enhancement by filtering}

The enhancement of these lineaments by filtering consists of highlighting these two characteristics in the image. To do this, so-called filtering techniques are used to eliminate all unnecessary data (noise) that masks the desired information contained in the image. The filtering techniques used in remote sensing are of two types: spatial and directional filtering (Tassine 2014).

Convolution spatial filtering makes it possible to assign to each of them a numerical value different from the original value while taking into account the values of the neighbouring pixels. This change in the value of the central pixel is equal to the sum of the products

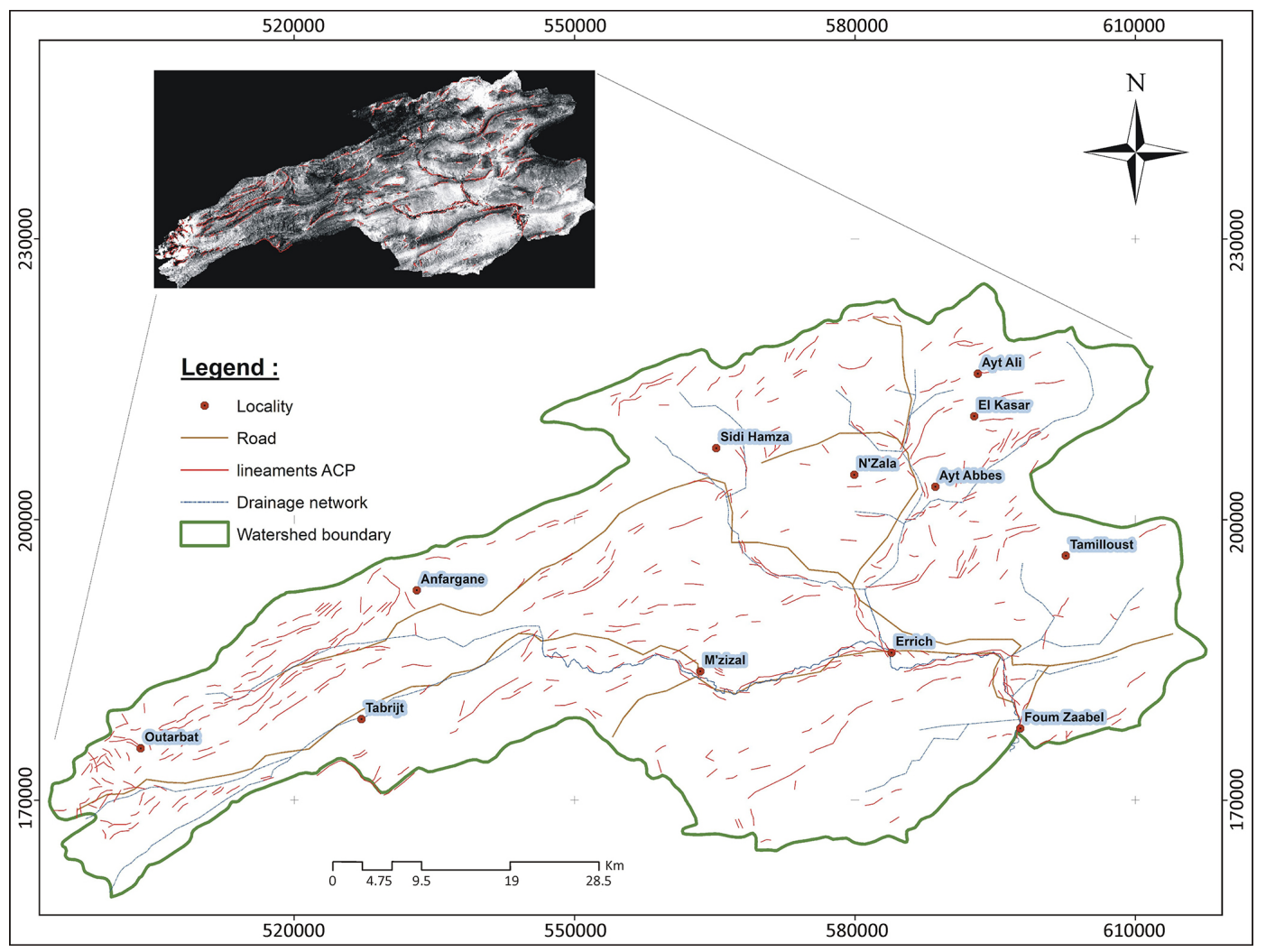

Fig. 4. Results obtained after extracting lineaments from Landast 8 OLI image 
of the pixel value multiplied by the value of the corresponding element in the matrix, divided by the number of elements.

Directional filtering ensures that the image is illuminated by a grazing light source and produces an optical shadow effect on it (Marrion 1987), this allows linear structures to be highlighted. The lineaments underlined by these filtering techniques are perpendicular to the direction of the given filter. For example, N-S direction filters allow the $\mathrm{E}-\mathrm{W}$ lineaments to be raised. In our study, we adopted directional filters that have been successfully used in several earlier studies (Laghouag 2011; Kouamé et al. 1999; Tassine 2014; Oubbih et al. 2015).

In order to detect and map as many linear structures as possible, we also used filters in the following directions $\mathrm{N}-\mathrm{S}, \mathrm{NE}-\mathrm{SW}, \mathrm{E}-\mathrm{W}$ and NW-SE.

\section{Analysis of preferential directions and validation of lineaments}

The processing and interpretation of satellite images is of great importance in the preparation of structural maps. To verify the quality of these results we compared the lineaments obtained by the image processing with the faults in the geological map (Fig. 5). It showed that the main fracture networks represented on this map had been detected, especially along the Rivers and their tributaries.

It can be seen that the lineaments detected by each filter are mainly dominated by its main direction. The sum of all the lineaments obtained in these directions is shown in (Fig. 6) which shows the dominance of the $\mathrm{N} 90-45^{\circ}$ (NE-SW) direction. The total lineaments being the sum of the lineaments obtained by the two techniques LINE and PCI.

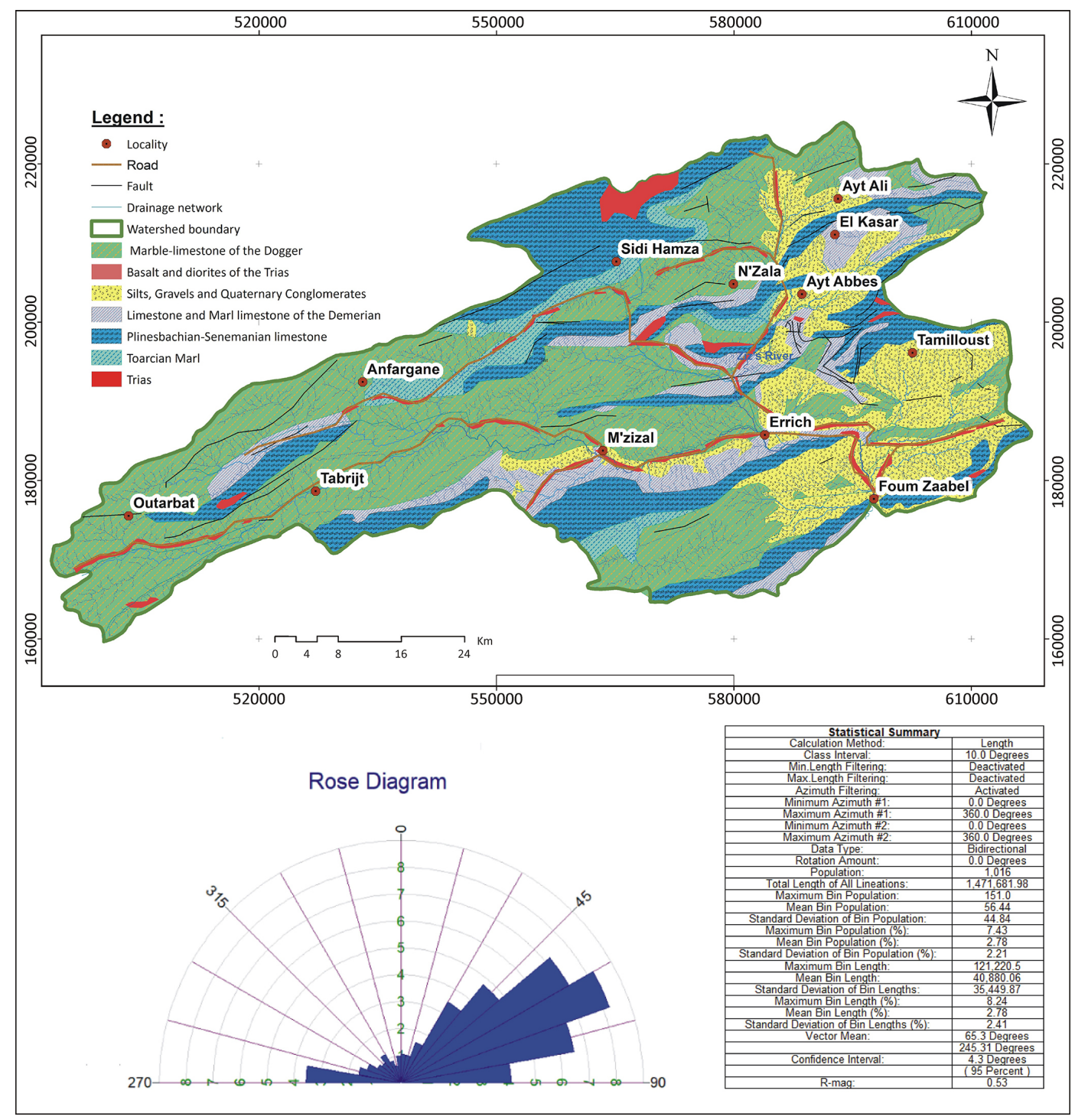

Fig. 5. Synthesis map of lineaments in the High Ziz River basin 
It is within this framework that we have made an attempt to elaborate a lineament map of the High $\mathrm{Ziz}$ River basin. The correlation of the results with the different orders of the hydrographic network will allow us to identify the potential effects of each family of faults on the orientations of surface water circulation.

The fracture orientation analysis showed that the directional rosettes of the cumulative lengths of the lineaments shown in the (Fig. 6) indicate some homogeneity of lineament directions and a preponderance $(90 \%)$ of $\mathrm{N} 90-45^{\circ}(\mathrm{NE}-\mathrm{SW})$ direction fractures. For $\mathrm{N} 45^{\circ}$ to $\mathrm{N} 0^{\circ}$ directions that have frequencies below $10 \%$ are less significant. These orientations seem to reflect background noise resulting from the variability of each family but also from geological contacts that can be confused with fractures. The superposition of the hydrographic net- work and a comparison of the results of previous work made it possible to validate the fractures obtained.

\section{Interpretation and Discussion}

\section{Analysis and lineament interpretation}

During the extraction of lineaments, discontinuities were found that correspond either to fractures showing a shift between geological formations or extensions of faults represented on the existing map, or to abnormal contact between two different geological formations without shift. Figure 5 presents the structural map of the entire network of new fractures mapped in the region.

To perform this spatial analysis, the image was cut into a grid of $8 \mathrm{~km}$ by $8 \mathrm{~km}$ cells. This allowed us to discern a smaller level of variation in the number of

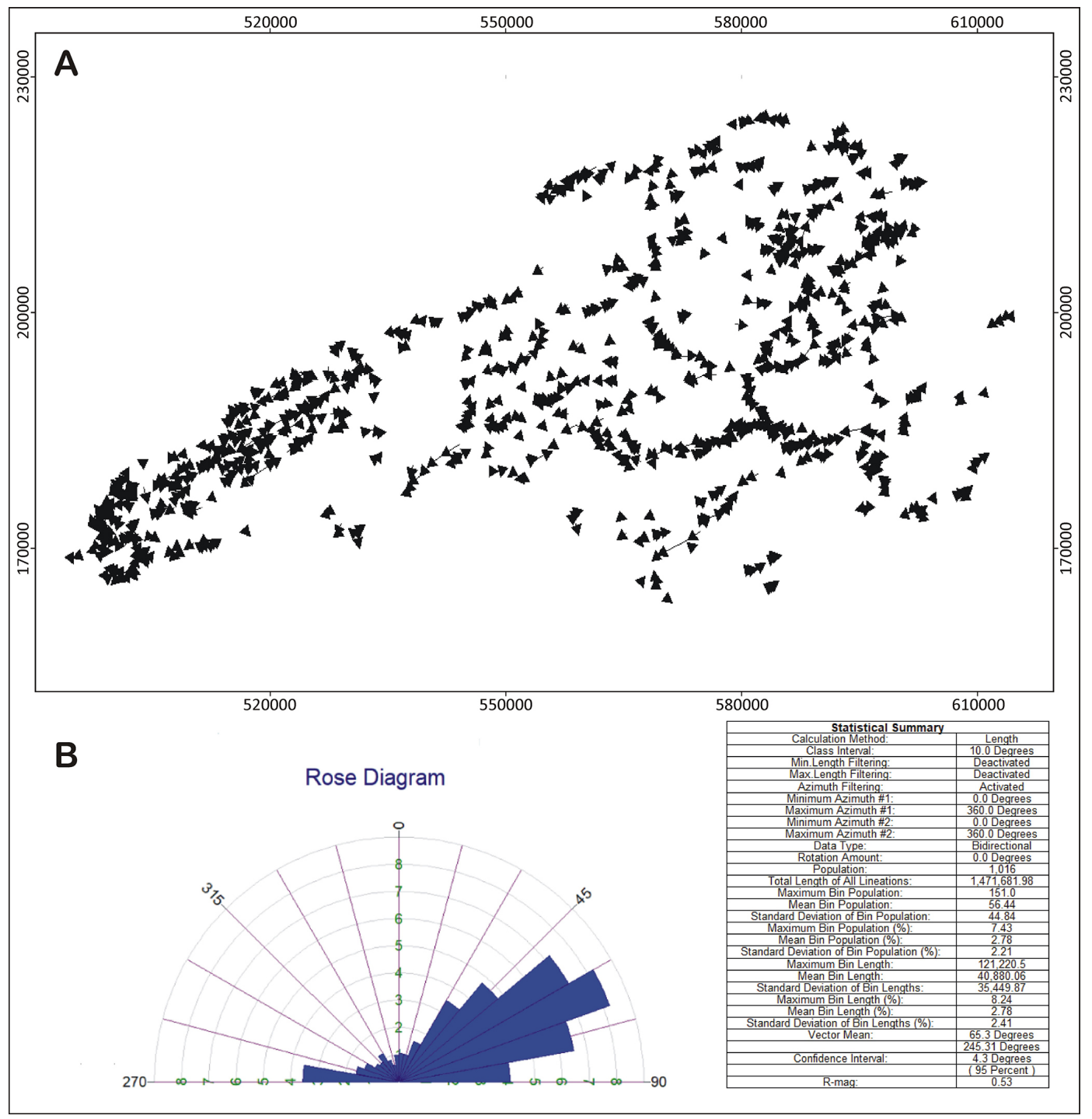

Fig. 6. Arrows of the cumulative lengths of the lineaments (A) and directional rosettes of the cumulative lengths of the lineaments (B) 
lineaments, on the one hand, and the variation in their density of interweaving on the other.

\section{Change in number of lineaments}

We analysed the variation in the number of lineaments over the entire image. The results obtained give an average of 1072 lineaments. It can be seen that this variation in the number of elements increases as one moves from West and North to South and South and South-East of the catchment area (towards the outlet of the HZR basin (Fig. 6). The large number of lineaments in the western zone of the catchment area could be related to the distribution of the population (colonization) of the lineaments in the area.

\section{Variation in the density of intersections}

The variation in the density of intersection takes almost the same variation in the numbers of lineaments; it becomes more and more important when moving from the West-Southwest and Central part of the basin to the South (Fig. 7), Very low densities occupy the Northwest and North of the basin.

\section{Confrontation of the river system with the lineaments}

The comparison of the hydrographic network with lineaments has made it possible to establish genetic links between fault orientations and the main directions of surface water circulation (Figs 6-8). The analysis of the satellite image showed the dominance of the
NE-SW direction with $90 \%$ of the lineaments identified, it also made it possible to illustrate the spatial and directional relationships that exist between these different elements and to evaluate the impact or influence of these lineaments on the flow and storage of surface water. This study also aims to produce a map of the geometry of the structures that complement the existing work carried out in the area.

In the case of the HZR basin, the total length of the rivers is $190.9 \mathrm{~km}$. These rivers drain an area of over 4,000 square kilometers. The Ziz River network is classified according to the classification of Strahler (1952) into seven major stream orders (from orders 1 to 7 ). All tributaries (Ziz rivers) meet in different directions. Streams of 5, 6 and 7 orders have a clear dominance of NE-SW directions while the other orders appear in $\mathrm{N}-\mathrm{S}$ directions mostly. This has an impact on the distribution of the total hydrographic network, which is dominated by the same directions NE-SW and N-S.

This orientation is that of the main lithological whole (Cailleux 1978; Tahiri 1991; Oubbih et al. 2015). Its influence is perceptible on the entire riverine network, particularly on the tributaries of orders 5, 6 and 7 illustrated in Figure 8. Almost all streams of the orders from 5 to 7 follow the lineaments because of the topography of the region and because of the presence of slopes generally directed towards the SW and from the North to the South of the High Ziz River basin. This favours the flow of water to the outlet.

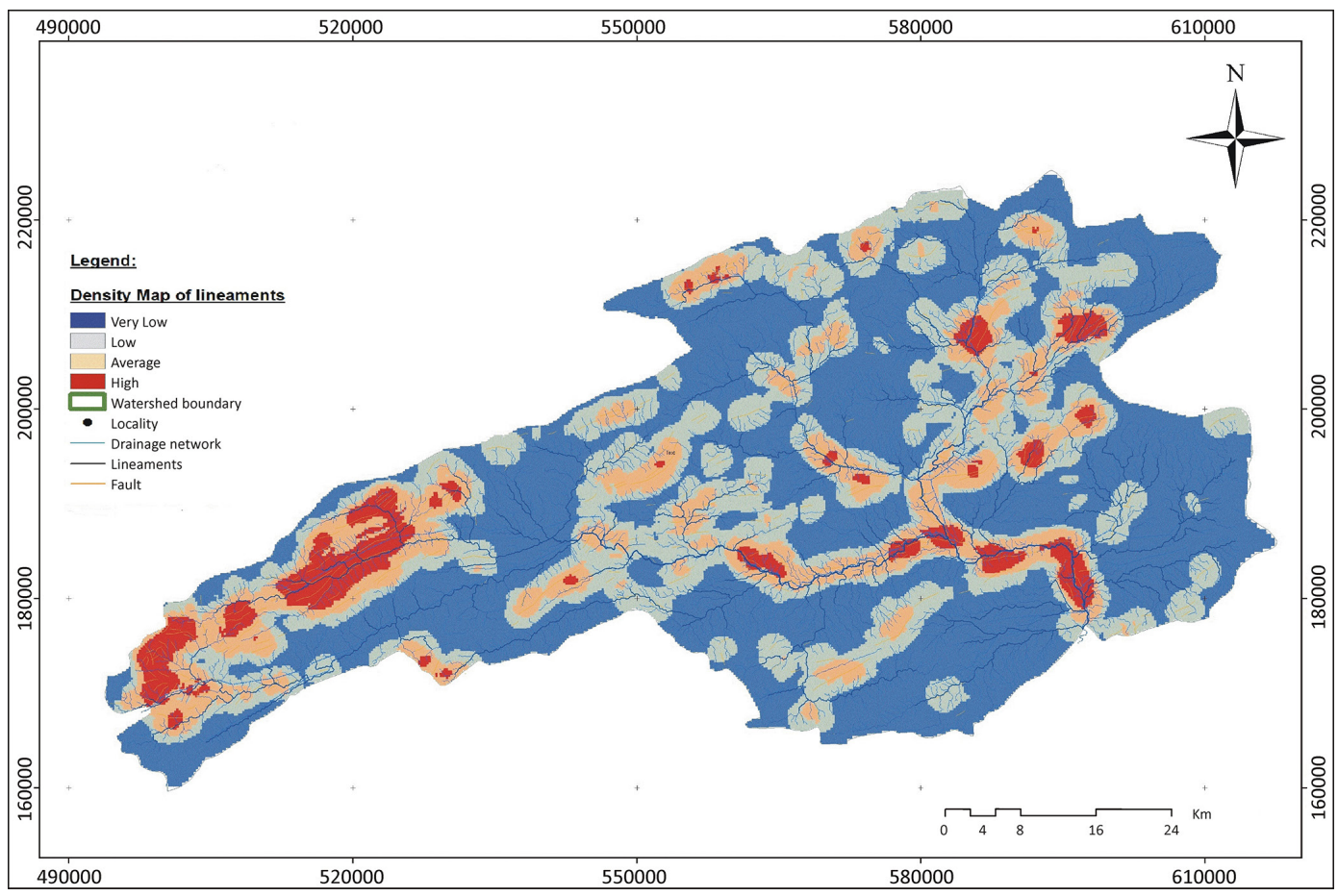

Fig. 7. Density Map of lineaments in the High Ziz River basin 


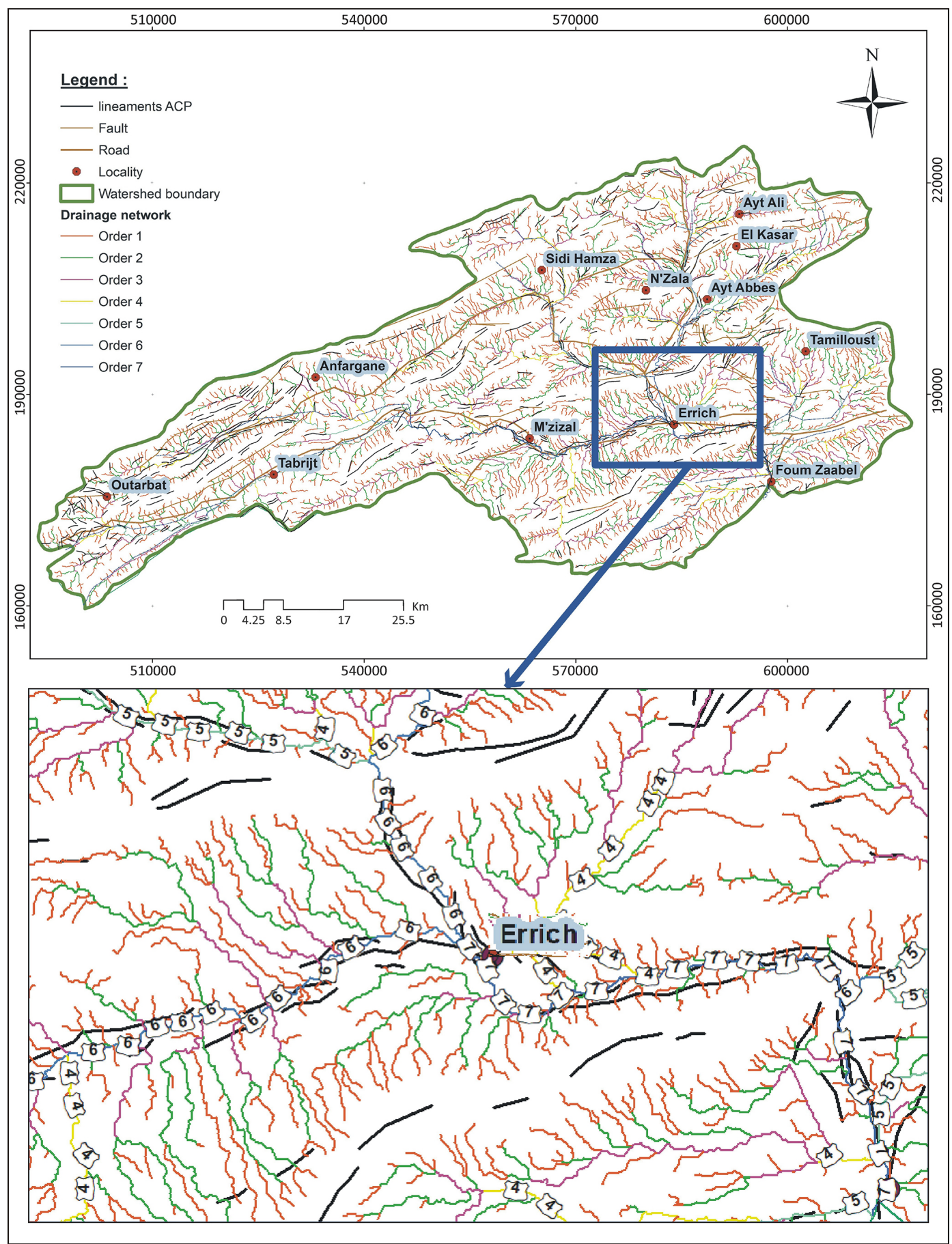

Fig. 8. Comparison of the hydrographic network with the lineaments of the High Ziz River basin

\section{Conclusion}

The analysis of the Landast 8 Oli satellite image and the extraction of the lineament network; its superposition and comparison with the hydrographic network of the HZR basin, which has been mapped, allowed the spatial and directional relationships that exist between these different elements to be illustrated, and the im- pact or influence of these lineaments on the flow and storage of water surface to be evaluated.

This study also aims to produce a map of the geometry of the structures that complement previous work carried out in the area. Statistical analysis of lineaments using directional rosettes showed a particular distribution of their orientation according to the preferred NESW direction with $90 \%$ frequency. The density, num- 
ber and continuity of the lineaments obtained in our case reveal their influence on the direction of the flow of surface water to the outlet to be determined by two essential parameters which are, on the one hand, geological structures, in particular fracturing, and on the other the topography characterized by slopes generally oriented towards the NE.

Some lineaments coincide with geological fractures existing in the field (faults). Their comparison with the hydrographic network shows that the majority of rivers follow NE-SW directions and are influenced by geological structures, particularly fracturing. The topography of the region also has an impact on flows.

\section{References}

Biémi J., 1992, Contribution à létude géologique, hydrogéologique et par télédétection des bassins versants sub-sahéliens du socle précambrien d'Afrique de l'Ouest: hydrostructurale, hydrodynamique, hydrochimie et isotopie des aquifères discontinus de sillons et aires granitiques de la Haute Marahoué, Côte d' Ivoire (Contribution to the geological, hydrogeological and remote sensing study of the sub-Sahelian watersheds of the Precambrian basement of West Africa: hydrostructural, hydrodynamic, hydrochemistry and isotopy of discontinuous aquifers of furrows and granitic areas of the Haute Marahoué, Ivory Coast) [PhD thesis], Université d'Abidjan, Abidjan, 480 pp. (in French)

Cailleux Y., 1978, Géologie de la région des Smaâla (Massif central marocain). Stratigraphie du Paléozoïque. Tectonique hercynienne (Geology of the Smaâla region (Moroccan Massif Central). Paleozoic stratigraphy. Hercynian tectonics), Notes Mém. Serv. Géol. Maroc. 40(275): 7-106. (in French)

Deffontaines B., 1990, Développement d`une méthodologie morpho-néotectonique et morphostructurale. Analyse des surfaces enveloppes, du réseau hydrographique et des modèles numériques de terrain; application au Nord-Est de la France (Development of a morphoneotectonic and morphostructural methodology, Analysis of envelope surfaces, the hydrographic network and digital terrain models, Application in the North East of France) $[\mathrm{PhD}$ thesis], Univ. Paris VI, Paris, 260 pp. (in French)

Gronayes C.P., 2003, Identification de couloirs de cisaillement à partir de l'imagerie TM de Landsat: application à l'archéen de Bloléquin, ouest de la Côte d'Ivoire (Identification of shear zones from Landsat TM imagery: application to the Archean of Bloléquin, western Ivory Coast), Télédetection 3(2-4): 217-226. (in French)

Jourda J.P., 2005, Méthodologie d'application des techniques de télédétection et des systèmes d'information géographique à l'étude des aquifères fissurés d'Afrique de l'Ouest. Conceptde l'hydrotechniquespatiale: cas des zones tests de la Côte-d'Ivoire (Methodology for applying remote sensing techniques and geographic information systems to the study of cracked aquifers in West Africa. Concept of spatial hydrotechnics: case of the test areas of the Ivory Coast) [PhD thesis], Université d'Abidjan, Abidjan, 429 pp. (in French)

Katsuaki S.N., 1995, Lineament analysis of satellite images using a segment tracing algorithm (STA), Comput. Geosci. 21(9): 1091-1104.

Kouamé G.P., Gioan P., Biémi J., Affian K., 1999, Méthode de cartographie des discontinuités-images satellitales : Exemple de la région semi-montagneuse à louest de la Côte d'Ivoire (Satellite image discontinuity mapping method: Example of the semi-mountainous region west of the Ivory Coast), Télédétection 2: 139-156. (in French) Laghouag M., 2011, Apport de la télédétection (images Landsat 7ETM+) pour la cartographie géologique de la région d'Aflou, Atlas saharien (Contribution of remote sensing (Landsat 7ETM + images) for the geological mapping of the Aflou region, Saharan Atlas) [Thesis], Universite Ferhat Abbas-Setif, Alger, 101 pp. (in French)

Marghany M.E., 2010, Lineament mapping using multispectral remote sensing satellite data, Int. J. Phys. Sci. 5(10): 1501-1507.

Marrion A., 1987, Introduction aux techniques de traitement d'image (Introduction to image processing), Ed. Eyrolles, Paris, 278 pp. (in French)

Oubbih J.E., El-Mahdaouy A., El-Mansouri B., Mridekh A. Chakiri S., Elbelrhiti H., 2015, Impact de la fracturation sur l'architecture du réseau hydrographique (cas de la région de Smaal, Maroc central Hercynien) Apport du SIG et de la télédétection (Impact of fracturing on the architecture of the hydrographic network (case of the Smaal region, central Hercynian Morocco) Contribution of GIS and remote sensing), Eur. Sci. J. 11(3): 342-360. (in French)

Papon A.E., 1973, Géologie et minéralisation du Sud-Ouest de la Côte d'Ivoire, Mém. Bur. Rech. Geol. Min. 80, Paris, 284 pp. (in French)

Rompel A.K.K., Koné A.M., Buvenich T.M.I.A.G., 1988, Structural interpretation of the Hana-Lobo Concession area, western Ivory Coast, Int. AAC Report 15/133/500/98/78, 23 pp.

Saley M.B., 2003, Cartographie thématique des aquifères de fissures pour lévaluation des ressources en eau. Mise en place d'une nouvelle méthode d'extraction des discontinuités images et d'un SIHRS pour la région semi-montagneuse de Man Nord-Ouest de la Côte d'Ivoire (Thematic mapping of fissure aquifers for the assessment of water resources. Implementation of a new method for extracting image discontinuities and a SIHRS for the semi-mountainous region of Man North-West of the Ivory Coast) [PhD Thesis], Uniwersytet Félix Houphouët-Boigny, Cocody-Abidjan, 209 pp. (in French)

Soesilo I., Hoppin R.,1986, Evaluation of digitally processed Landsat imagery and SIR-A imagery for geological analysis of West Java région, Indonesia, Proc. of the 7th International Symposium on Remote Sensing for Resources 
Development and Environmental Management, Enschede, Netherlands, 25-20 August, Rotterdam-Boston, 173-1 82.

Strahler A., 1952, Hypsometric (area-attitude) analysis of erosion topology, Geol. Soc. Am. Bull. 63(11): 1117-1142.

Tahiri A., 1991, Le Maroc central septentrional: stratigraphie, sédimentologie et tectonique du Paléozoïque; un exemple de passage des zones internes aux zones externes de la chaîne hercynienne du Maroc (Northern central Morocco: Palaeozoic stratigraphy, sedimentology and tectonics; an example of passage from internal zones to external zones of the hercynian chain of Morocco) [PhD Thesis], Universite de Bretagne Occidentale, Brest, 311 pp. (in French)

Walsh G.J., Clark S.F., Jr, 2000, Contrasting methods of fracture trend characterization in crystalline metamorphic and igneous rocks of the Windham quadrangle, New
Hampshire, Northeastern Geol Environ. Sci. 22(2): 109120.

Yatabe S.M., Howarth P.J., Hogg W.A., Bruce B.D, 1984, Airborne MSS and MEIS II data for lineament enhancement in Northern Ontario, Proc. of the 9th Canadian Symposium on Remote Sensing, Newfoundland, August 14-17, St John's, 375-385.

Youan T.M., 2008, Contribution de la télédétection et des systèmes d'informations géographiquesà la prospection hydrogéologique du socle précambrien d'Afrique de l'Ouest: Cas de la région de Bondoukou, nord-est de la Côted'Ivoire (Contribution of remote sensing and geographic information systems to the hydrogeological prospecting of the Precambrian basement of West Africa: Case of the Bondoukou region, north-east of the Ivory Coast) $[\mathrm{PhD}$ Thesis], Uniwersytet Félix Houphouët-Boigny, CocodyAbidjan, 236 pp. (in French) 